\title{
Original article (Orijinal araştırma) Susceptibility of Chilo partellus Swinhoe, 1885 (Lepidoptera: Crambidae)
to some commonly used insecticides
}

\author{
Chilo partellus Swinhoe, 1885 (Lepidoptera: Crambidae)'un yaygın olarak kullanılan \\ insektisitlere duyarlılığı
}

\author{
Tange Denis ACHIRI ${ }^{1}$
}

\author{
Ekrem ATAKAN ${ }^{1}$
}

\author{
Serkan PEHLIVAN ${ }^{1^{*}}$
}

\begin{abstract}
Chilo partellus Swinhoe, 1885 (Lepidoptera: Crambidae), a destructive pest of maize, was recently recorded in the Mediterranean Region of Turkey. The pest is considered to be an invasive species, displacing indigenous stem borers in many parts of the world. The aim of the study was to determine the effect of commonly used insecticides in a maize production system in Turkey on egg hatch and mortality of first instar larvae of $C$. partellus under laboratory conditions $\left(27 \pm 2^{\circ} \mathrm{C}, 70 \% \mathrm{RH}\right.$ and 14:10 $\mathrm{h} \mathrm{L}: \mathrm{D}$ photoperiod) at the Plant Protection Department, Faculty of Agriculture, University of Çukurova. Eight insecticides registered for indigenous lepidopteran pests were used at the recommended rates. The percentage of hatched egg masses were significantly different. The smallest percentage was $30.6 \%$ with deltamethrin. The percentages of hatched egg masses were greater than $80 \%$ for all other insecticides. Mortality of hatched larvae was significantly different. The highest and lowest mortalities of hatched larvae were $84.5 \%$ and $38.2 \%$ with emamectin-benzoate and lambda-cyhalothrin, respectively. Seventy-two $\mathrm{h}$ after exposure of the first instar larvae to sprayed maize leaf disks, the lowest and highest mortalities were $62.6 \%$ and $96.7 \%$ with indoxacarb and emamectinbenzoate, respectively. Survival analyses revealed that hazard ratios ranged from 4.91 (95\% Cl: 1.66-14.6) to 15.6 (95\% Cl: 5.33-45.6) with chlorpyrifos-ethyl and emamectin-benzoate, respectively. The mortality of first instar larvae was about 16, 10 and 9 times that of the control with emamectin-benzoate, lambda-cyhalothrin and deltamethrin, respectively. Feeding activity of larval stage was reduced by all treatments. The implications of this study are discussed.
\end{abstract}

Keywords: Black-head stage, Chilo partellus, hatch, mortality, survival, Turkey

\section{Öz}

Chilo partellus Swinhoe, 1885 (Lepidoptera: Crambidae), Türkiye'de Akdeniz Bölgesi'nde son zamanlarda saptanan oldukça zararı bir mısır zararlısıdır. İstilacı bir tür olarak değerlendirilen C. partellus, dünyanın birçok bölgesinde diğer yerli mısırkurtlarının yerini almaktadır. Bu amaçla, Türkiye'de mısır üretim alanlarında diğer Lepidopter türlerine karşı yaygın olarak kullanılan 8 insektisidin önerilen dozlarının $C$. partellus'un yumurta ve birinci dönem larvalarına etkisi, Çukurova Üniversitesi Ziraat Fakültesi Bitki Koruma Bölümü laboratuvarında $27 \pm 2^{\circ} \mathrm{C}, \% 70$ orantılı nem, 14:10 (A: K) koşullarda araştırıımıştı. Bu çalışmayla insektisitlerin yumurtaların açıma oranları ve larva ölüm oranları üzerinde etkili olduğu bulunmuştur. En düşük açılma oranı deltamethrinde $\% 30.6$ olarak belirlenmiştir. Diğer tüm insektisit uygulamalarında yumurta açılma oranları \%80'nin üzerinde saptanmıştır. Larvaların ölüm oranlarında ise en yüksek oran \%84.5 ile emamectin-benzoat'ta belirlenirken, en düşük oran \%38.2 ile lambda-cyhalothrinde belirlenmiştir. Innsektisite daldırılmış mısır yaprak disklerinde ise birinci dönem larvaların en düşük ve en yüksek ölüm oranları, 72 saat sonra indoxacarb ve emamectin-benzoat için sırasıyla $\% 62.6$ ve \% 96.7 olmuştur. Hayatta kalma analizleri, risk oranlarının chlorpyrifos-ethyl ve emamectin-benzoat için sırasıyla 4.9 (\%95 Cl: 1.66-14.6) ile 15.6 (\%95 Cl: 5.33-45.6) arasında değiştiğini göstermiştir. Birinci dönem larvalarının ölüm oranlarının kontrol ile kıyaslandığında emamectin-benzoate, lambda-cyhalothrin ve deltamethrinde sırasıyla 16, 10 ve 9 kat yüksek olduğu belirlenmiştir. Ayrıca tüm uygulamalarda larvaların davranışlarında azalma gözlenmiştir.

Anahtar sözcükler: Siyah-baş dönemi, Chilo partellus, yumurta açılma, ölüm oranı, yaşam, Türkiye

\footnotetext{
${ }^{1}$ Çukurova University, Faculty of Agriculture, Department of Plant Protection, 01330, Adana, Turkey

* Corresponding author (Sorumlu yazar) e-mail: spehlivan@cu.edu.tr

Received (Alınış): 22.08.2019Ａccepted (Kabul ediliş): 11.12.2019

Published Online (Çevrimiçi Yayın Tarihi): 07.02.2020
} 


\section{Introduction}

The maize spotted stem borer, Chilo partellus Swinhoe, 1885 (Lepidoptera: Crambidae), originally from the Indian subcontinent (Harris, 1989) has been reported in many parts of the world especially in Asia, eastern and southern parts of Africa (Ndema et al., 2001; Kfir et al., 2002; Melaku et al., 2006; Mutyambi et al., 2014), and recently in the Mediterranean Basin (Yonow et al., 2017). Owing to its ability to survive in low and high elevations (Kfir, 1993, 1997; Guofa et al., 2001), and on a broad temperature spectrum (Kfir, 1997; Mutamiswa et al., 2017), and higher potential rate of increase and shorter life cycle (Kioko et al., 1995; Kfir, 1997; Ofomata et al., 2000), C. partellus gains competitive advantage over other maize stem borers. Chilo partellus is described as an invasive species displacing indigenous maize stem borers and becoming the predominant borer pest (Overholt et al., 1994; Kfir, 1997; Ofomata et al., 2000).

Chilo partellus is known to cause severe damage to maize and sorghum wherever it is found (Kfir et al., 2002; Arabjafari \& Jalali, 2007). Not only does it damage the vegetative parts of the plant, but it also damages the reproductive parts, causing losses between 24 and $75 \%$ (Kumar, 2002), and 80 and 100\% in severe infestation in Asia and Africa (Overholt et al., 2000; Arabjafari \& Jalali, 2007). The normal damage patterns characteristic of maize stem borers includes bored holes on stems and destroyed internal stem tissue resulting into tunnels (Slabbert \& Van den Berg, 2009) and a mixture of rotten, pungent insect and plant tissue debris within the stems. Consequently, the damaged plant is prone to toppling and lodging from any form of disturbance such as heavy rains, storms and strong winds. In addition, C. partellus like many other stem borers feed and destroy the growing apex of the maize plant resulting into a condition called deadheart; the growing central leaves die, the plant become stunted and/or dies (Rauf et al., 2017).

Several control and management methods have been employed in an attempt to reduce the damage caused by $C$. partellus. Murenga et al. (2011) presented some control strategies for $C$. partellus and discussed their shortcomings. Resistant maize cultivars have been tried with some success (Ajala et al., 1995; Ahmed et al., 2003; Murenga et al., 2011). Parasitoids such as Cotesia spp. (Hymenoptera: Braconidae) and Trichogramma spp. (Hymenoptera: Trichogrammatidae) have also been used for control of C. partellus with relative success (Kfir et al., 2002; Ahmed et al., 2003). Recently, push-pull technology has gained prominence with a huge adoptability rate especially in the eastern parts of Africa. With regards to push-pull technology, brachiara and Napier grass are among the most commonly used grasses (Van den Berg, 2006; Cheruiyot et al., 2018). The use of pheromones (Beevor et al., 1990), essential oils (Sing et al., 2009) and microorganism-based products (Odindo, 1990; Poinar \& Polaszek, 1998) are also gaining grounds. Intercropping is also successfully used for reduction of infestation (Ampong-Nyarko et al., 1994; Pats et al., 1997) up to $30 \%$ in maize/sorghum/cowpea-intercropping systems. Other cultural practices such as manipulating planting dates (Van Hamburg, 1979), management of crop residue (Pats et al., 1997), and fertilizer application are also being investigated and used (Van den Berg et al., 1991). However, insecticides applied in foliar and granular formulations are also widely used as preferred solution by farmers since they remain the most convenient control method (Rauf et al., 2017). The insecticides are most effective if applied in the initial stages of an infestation in order to prevent egg hatch and eliminate first and second instar larvae before burrowing in the maize stems (Kfir et al., 2002; Kumar, 2002). In Pakistan, foliar application of fenvalerate, endosulfan, cypermethrin, monocrotophos, quinalphos, and granular application of chlorpyrifos-ethyl and carbofuran are commonly recommended for management of maize stem borers (Mathur \& Satyadev, 1992; Katole \& Mundiwate, 1995; Bhat \& Baba, 2007). Entomopathogens (Odindo, 1991; Gardeze et al., 1998) and novel insecticides such as novaluron, spinosad, emamectin-benzoate have also shown promising results against $C$. partellus (Rameash et al., 2012). Cypermethrin, carbofuran and methamidophos are commercially available in India against the maize stem borers (Khan \& Amjad, 2000). According to Van den Berg \& Van den Westhuizen (1995), endosulfan and deltamethrin are also used against Chilo partellus in South Africa. 
Recently, the spotted stem borer was recorded in the Mediterranean Region of Turkey in 2014 (Sertkaya et al., 2014) causing a stir among maize farmers, who have been battling with the voracious indigenous lepidopteran maize stem borer pests such as Sesamia nonagrioides (Lefebvre, 1827) (Lepidoptera: Noctuidae) Ostrinia nubilalis Hübner, 1796 (Lepidoptera: Crambidae), and Spodoptera sp. (Lepidoptera: Noctuidae) especially in the second maize growing season, July-October (Okyar \& Kornoşor, 1997). Farmers in Turkey rely almost entirely on insecticides to control maize stem borers. While research is ongoing on the population dynamics and other aspects of $C$. partellus, preliminary results reveal that it is present in maize in Turkey in both the first (April-June) and second (July-October) maize growing seasons, with an infestation rate of 5 to $55 \%$ and 20 to $90 \%$, respectively (unpublished data). There are currently no prescribed insecticides in the Turkish market registered for $C$. partellus control. This study was designed to evaluate the potential of some insecticides used against other stem borers for control of $C$. partellus. As such, eight commonly used insecticides in maize production systems used against stem borers in Turkey were screened on eggs and first instar larvae of the spotted stem borers under laboratory conditions.

\section{Materials and Methods}

\section{Stem borer colony}

The stem borer colony used in this study was the F1 generations of field-collected larvae of $C$. partellus. In June 2018, larvae were collected from a maize field (not sprayed with insecticides) in the Research and Implementation Area of Çukurova University (39 $\left.01^{\prime} 50.5^{\prime \prime} \mathrm{N} ; 35^{\circ} 21^{\prime} 06.7^{\prime \prime} \mathrm{E}\right)$. The larvae were reared on insecticide-free maize stalks (Pioneer Hybrid 1/2013) in the entomology laboratory of Plant Protection Department, Faculty of Agriculture, University of Çukurova. The maize stalks were cut $(10 \mathrm{~cm})$ and packed in plastic cups $(10 \times 10 \times 10 \mathrm{~cm})$ covered with a muslin and fitted with a rubber band. The maize stalks were replaced every 5-6 d until pupation. Upon pupation, the pupae were kept in new plastic jars $(10 \times 10 \times 10 \mathrm{~cm})$ lined with a Whatman filter paper for oviposition and covered with a muslin. A cotton ball soaked in water was added in the plastic jar for the adults. Egg masses were laid on the filter paper and these were collected daily for bioassays. The eggs and larvae from these F1 generations were used in the study.

\section{Insecticides used in the bioassay}

Table 1 shows the list of selected insecticides commonly used in maize production systems or registered for other lepidopteran stem borers in Turkey. The insecticides which have different mode of actions such as nerve action, chloride channel activator and insect growth regulators were used. Pesticides were used at the manufacturer's recommendation for other lepidopteran stem borer pests of maize, diluted in distilled water. Topical and leaf-dip bioassay were used for the hatching and mortality studies, respectively.

\section{Bioassay}

\section{Effect of insecticides on egg hatch}

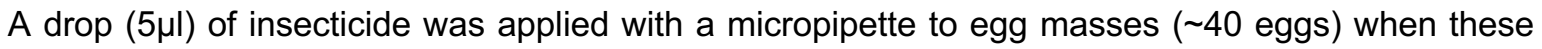
were at the black-head stage (4-5 d old), after which the eggs usually hatch within $24 \mathrm{~h}$. The egg mass was placed on a maize leaf disk $(5 \mathrm{~cm})$, and then placed on a water-soaked cotton in a cup $(5 \mathrm{~cm} \mathrm{diam} . \times 2.5 \mathrm{~cm}$ high). A hole $(1 \mathrm{~cm})$, covered with muslin, was perforated on the lid of the cup. There were three replicates per treatment. The setup was kept in a rearing chamber $\left(27 \pm 2^{\circ} \mathrm{C}, 70 \% \mathrm{RH}\right.$ and 14:10 h L:D photoperiod). The number of eggs hatched was counted $24 \mathrm{~h}$ after insecticide application. 
Table 1. Tested Insecticides; description, formulations and uses

\begin{tabular}{|c|c|c|c|c|c|c|}
\hline $\begin{array}{l}\text { Active ingredient (ai) } \\
\text { / Trade name / Firm } \\
\text { name / Country }\end{array}$ & Con. / Form. & $\begin{array}{c}\text { Field rate } \\
\quad(\text { ai } \%)\end{array}$ & $\begin{array}{l}\text { Rates } \\
(\mathrm{ppm})\end{array}$ & Chemical family & Mode of action & Crops \\
\hline
\end{tabular}

name / Country

Ingestion and

contact. Nicotinic

Spinosad / LaserTM

/ Dow AgroSciences

/ United Kingdom

$480 \mathrm{~g} \mathrm{~L}^{-1} / \mathrm{SC} \quad 200 \mathrm{ml} \mathrm{ha}^{-1} \quad 200 \quad$ Spinosyn
$25 \mathrm{~g} \mathrm{~L}^{-1} / \mathrm{EC} \quad 500 \mathrm{ml} \mathrm{ha}^{-1} \quad 5000 \quad$ Pyrethroid

Decis ${ }^{\circledR} /$ Bayer

CropScience /

France acetylcholine

(nAChR) receptor

agonist. Nerve

action.
Tomato, eggplant,

pepper, potato

strawberry,

legumes, pome

fruits, vegetables,

ornamental plants

grass

Pear, vegetables,

Ingestion and contact. Paralyses nervous system; knockdown effect. grapes, pistachio, lentil, chickpea, maize, beet, Lepidoptera

aphids, cereals, sunflower, Coleoptera hazelnut
Lepidoptera,

Coleoptera,

Diptera

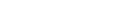

\begin{tabular}{|c|c|c|c|c|c|c|c|}
\hline & & & & & & & \\
\hline $\begin{array}{l}\text { Lambda-cyhalothrin / } \\
\text { Karate }^{\circledR} / \text { Syngenta } \\
\text { Chemicals / Belgium }\end{array}$ & $50 \mathrm{~g} \mathrm{~L}^{-1} / \mathrm{CS}$ & $300 \mathrm{ml} \mathrm{ha}^{-1}$ & 3000 & Pyrethroid & $\begin{array}{l}\text { Ingestion and } \\
\text { contact. Paralyses } \\
\text { nervous system; } \\
\text { knockdown effect. }\end{array}$ & $\begin{array}{l}\text { Maize, cotton, } \\
\text { apple, grapes, } \\
\text { potatoes, beet, } \\
\text { tomatoes, nuts, } \\
\text { cabbage, cereals, } \\
\text { olive }\end{array}$ & $\begin{array}{l}\text { Lepidoptera, } \\
\text { mites, aphids }\end{array}$ \\
\hline $\begin{array}{l}\text { Chlorantraniliprole / } \\
\text { Coragen }{ }^{\circledR} / \text { DuPont / } \\
\text { France }\end{array}$ & $200 \mathrm{~g} \mathrm{~L}^{-1} / \mathrm{SC}$ & $150 \mathrm{ml} \mathrm{ha}^{-1}$ & 1500 & Anthanilic diamide & $\begin{array}{l}\text { Ingestion. } \\
\text { Ryanodine } \\
\text { receptor } \\
\text { modulator. }\end{array}$ & $\begin{array}{l}\text { Tomato, eggplant, } \\
\text { pepper, cucurbit } \\
\text { crops, leafy } \\
\text { vegetables, maize, } \\
\text { peach, quince, } \\
\text { plum }\end{array}$ & Lepidoptera \\
\hline $\begin{array}{l}\text { Indoxacarb / } \\
\text { Tunchii }^{\circledR} \text { / Astranova } \\
\text { / Turkey }\end{array}$ & $150 \mathrm{~g} \mathrm{~L}^{-1} / \mathrm{SC}$ & $300 \mathrm{ml} \mathrm{ha}^{-1}$ & 3000 & Oxadiazine & $\begin{array}{l}\text { Ingestion and } \\
\text { contact. Voltage- } \\
\text { dependent sodium } \\
\text { channel blocker. }\end{array}$ & $\begin{array}{l}\text { Tomato (field and } \\
\text { greenhouse), } \\
\text { hazelnut, maize }\end{array}$ & Lepidoptera \\
\hline $\begin{array}{l}\text { Chlorpyrifos-ethyl / } \\
\text { Dursban }{ }^{\circledR} 4 \text { / Dow } \\
\text { AgroSciences / } \\
\text { United Kingdom }\end{array}$ & $480 \mathrm{~g} \mathrm{~L}^{-1 /} \mathrm{EC}$ & $1800 \mathrm{ml} \mathrm{ha}^{-1}$ & 1800 & Organophosphate & $\begin{array}{l}\text { Ingestion and } \\
\text { contact. Inhibits } \\
\text { cholinesterase. } \\
\text { Nerve action. }\end{array}$ & $\begin{array}{l}\text { Pear, vegetables, } \\
\text { grapes, pistachio, } \\
\text { lentil, chickpea, } \\
\text { maize, beet, } \\
\text { cereals, sunflower, } \\
\text { hazelnut, cotton }\end{array}$ & Lepidoptera \\
\hline $\begin{array}{l}\text { Emamectin- } \\
\text { benzoate / Pancart }{ }^{\circledR} / \\
\text { Platin Kimya / } \\
\text { Turkey }\end{array}$ & $5 \% / S G$ & $300 \mathrm{~g} \mathrm{ha}^{-1}$ & 3000 & Avermectin & $\begin{array}{l}\text { Ingestion. Chloride } \\
\text { channel activator. }\end{array}$ & $\begin{array}{l}\text { Pepper, tomato } \\
\text { (field and } \\
\text { greenhouse) }\end{array}$ & Lepidoptera \\
\hline $\begin{array}{l}\text { Novaluron / RIMON } \\
\text { SUPRA }^{\circledR} / \text { Adama / } \\
\text { Israel }\end{array}$ & $100 \mathrm{~g} \mathrm{~L}^{-1} / \mathrm{SC}$ & $400 \mathrm{~g} \mathrm{ha}^{-1}$ & 4000 & $\begin{array}{l}\text { Benzoylphenyl } \\
\text { urea }\end{array}$ & $\begin{array}{l}\text { Ingestion and } \\
\text { contact. Insect } \\
\text { Growth Regulator- } \\
\text { inhibits chitin } \\
\text { synthesis. }\end{array}$ & $\begin{array}{l}\text { Tomato (field and } \\
\text { greenhouse), } \\
\text { pepper } \\
\text { (greenhouse), } \\
\text { cotton, soya, } \\
\text { cucumber }\end{array}$ & Lepidoptera \\
\hline
\end{tabular}

Con.: concentration; Form.: formulation; SC: suspension concentrate; SG: soluble granules; EC: emulsifiable concentrate;

CS: capsule suspension. 


\section{Effect of insecticides on survival of emerging larvae}

The first instar larvae hatched from insecticide-treated eggs were kept separately on fresh insecticidefree maize leaf disks. The leaf disks were kept on moist cotton in plastic cups ( $5 \mathrm{~cm}$ diam. $\times 2.5 \mathrm{~cm}$ high), and then covered with a perforated lid, sealed with a muslin for ventilation. There were three replicates per treatment. The setup was kept in the temperature chamber $\left(27 \pm 2^{\circ} \mathrm{C}, 70 \% \mathrm{RH}\right.$ and 14:10 $\mathrm{h} \mathrm{L}$ :D photoperiod). Mortality of the emerging larvae was assessed after $48 \mathrm{~h}$.

\section{Effect of insecticides on first instar larvae}

Leaf-dip bioassay was used to evaluate the effect of insecticides on first instar larvae of $C$. partellus. Fresh maize leaf disks $(2 \mathrm{~cm})$ were immersed in insecticide solution for $5 \mathrm{~s}$, and then allowed to dry for $1 \mathrm{~h}$ under laboratory conditions $\left(25 \pm 2^{\circ} \mathrm{C}\right)$. The leaf disks were then placed on moist cotton in cups and covered with a perforated lid, sealed with a muslin for ventilation. Ten first instar larvae of $C$. partellus, collected from F1 generation of laboratory reared field-collected larvae were placed on the leaf disk with the help of a fine camel hair brush. There were three replicates per treatment. The setup was kept in a climatic chamber set to $27 \pm 2^{\circ} \mathrm{C}, 70 \% \mathrm{RH}$ and $14: 10 \mathrm{~h} \mathrm{~L}: \mathrm{D}$ photoperiod. Mortality of the larvae was assessed every $12 \mathrm{~h}$ for $3 \mathrm{~d}(72 \mathrm{~h})$. A larva was considered dead if they did not move after being touched by a fine camel hair brush.

\section{Data analysis}

Normality and homogeneity of variance tests for the data were done using Kolmogorov-Smirnov and Levene's test, respectively. Percentage hatch of black-head stage eggs after $24 \mathrm{~h}$ was subjected to oneway analysis of variance (ANOVA) and means were separated by post hoc Duncan's multiple range test (DMRT) procedure at a significance level of 0.05 . Mortality of emerged larvae was assessed $48 \mathrm{~h}$ after hatching. Mortality of hatched larvae after $48 \mathrm{~h}$ and first instar larval mortality on insecticide-treated leaves after $72 \mathrm{~h}$ was analyzed (one-way ANOVA, DMRT, $\mathrm{P}<0.05$ ). The mortality was also assessed every $12 \mathrm{~h}$ for survival analysis.

Survival analysis, which is generally a set of methods for analyzing data where the outcome variable is the time until the occurrence of an event of interest (mortality), was conducted. Kaplan-Meier survival curves were used to estimate median survival times ( $\mathrm{LT}_{50}$; median survival time is the time at which $50 \%$ of the first instar larvae survive) $72 \mathrm{~h}$ after exposure to the insecticides and their respective $95 \%$ confidence intervals $(\mathrm{Cl})$ were determined. Hazard ratios after $72 \mathrm{~h}$ were estimated using Cox regression to estimate the probability of mortality of first instar larvae occurring in the insecticide-treated leaves compared to the water-treated (control) leaves at any given time. All analyses were done using Statistical Package for Social Sciences (Ver. 23, 2015).

\section{Results and Discussion}

\section{Effect of insecticides on hatch of black-head stage egg masses}

The effect of various insecticides on hatch of black-head stage egg masses of Chilo partellus are shown in Table 2. There was a significant difference $(F=41.2, d f=8,18, P<0.05)$ in the mean percentage of hatched egg mass exposed to different insecticides. The smallest percentage hatch $(30.6 \%)$ was with deltamethrin, followed by t chlorpyrifos-ethyl (86.3\%) and lambda-cyhalothrin (89.9\%). The percentage of eggs that hatched from the other insecticides was greater than $90 \%$. It is known that the chorion layer of lepidopteran egg is not particularly permeable to ovicidal and toxic chemicals; nevertheless, some chemicals can pass through. In such events, these toxic chemicals can negatively affect embryonic development and/or result in death (Trisyono et al., 2000; Galvan et al., 2005). Of all the insecticides, deltamethrin significantly prevented hatch of the black-head stage egg masses (Table 2). On average, hatch was about three times lower in deltamethrin relative to the other insecticides. It is not clear why there 
was inconsistency in the percentage hatch between deltamethrin and lambda-cyhalothrin as they are members of the same chemical class.

Pineda et al. (2004) reported that spinosad diluted in water did not exhibit any ovicidal activity in Spodoptera littoralis (Boisduval, 1833) (Lepidoptera: Noctuidae) eggs. However, when diluted in acetone, the percentage hatch was significantly reduced from $80-89 \%$ to $36.0 \%$ in water and acetone solvents, respectively. The effect of insecticide on hatching and other biological events in insects is affected by the solvent used. According to Adan et al. (1996) the penetration and deposition of insecticide into insect cuticle is facilitated by organic solvents. In another study, the number of $O$. nubilalis eggs hatching after treatment with indoxacarb, novaluron, spinosad and water (control) at the black-head stage was not significantly different (Boiteau \& Noronha, 2007). However, when the insecticides were sprayed $2 \mathrm{~d}$ before the blackhead stage, the number of eggs that hatched was significantly reduced compared to application at the black-head stage by 60,80 and $8 \%$ for indoxacarb, novaluron and spinosad, respectively. Mahmoudvan et al. (2014) also reported that indoxacarb SC $\left(300 \mathrm{mg} \mathrm{L}^{-1}\right)$ and spinosad $\left(480 \mathrm{mg} \mathrm{L}^{-1}\right)$ caused ovicidal control of 86 and $100 \%$, respectively on the egg masses of Plutella xylostella (L.,1758) (Lepidoptera: Plutellidae). Hexaflumuron (200 mg L-1), and lufenuron (1000 mg L-1) which are in the same group as novaluron, also gave ovicidal control of 100 and $50 \%$, respectively, in the same study. However, it should be noted that in the experiments of Mahmoudvan et al. (2014), the egg masses used were no more than $10 \mathrm{~h}$ old. This suggests that the effect of insecticides on egg hatch also depends on the age of the eggs; the younger the eggs, the more effective the insecticide. High ovicidal effect of novaluron on other lepidopteran has been reported in other studies (Assal et al., 1983; Chockalingam \& Noorjahan, 1984).

At the commercial recommended application rate, the percentage hatch of lepidopteran egg masses can be strongly influenced by the solvent (medium) of the insecticide and the age of egg mass. De Smedt et al. (2015) indicated that hydrophobic compounds are more likely to absorb the intermediate and nonpolar poly ( $p$-phenylene) PPPs, and therefore can easily attach to the hydrophobic egg surface, causing desiccation of the eggs. For this reason, perhaps, a decreased hatching percentage might have been observed had a hydrophobic solvent like acetone and young egg masses (hours old) been used.

Table 2. Mean percentage hatched black-head stage eggs of Chilo partellus $24 \mathrm{~h}$ after application of insecticides

\begin{tabular}{lcccc}
\hline \multicolumn{1}{c}{ Treatment } & Replicates & Egg/mass & Mean $(\%) \pm$ SEM & $95 \%$ confidence interval $(\mathrm{Cl})$ \\
\hline Control & 3 & $35-40$ & $98.2 \pm 0.65 \mathrm{c}$ & $97.3-99.2$ \\
Spinosad & 3 & $30-34$ & $91.6 \pm 2.07 \mathrm{bc}$ & $88.2-95.0$ \\
Deltamethrin & 3 & $32-40$ & $30.6 \pm 5.76 \mathrm{a}$ & $21.7-39.6$ \\
Lambda-cyhalothrin & 3 & $30-40$ & $89.9 \pm 1.20 \mathrm{bc}$ & $88.0-91.9$ \\
Emamectin-benzoate & 3 & $30-36$ & $95.8 \pm 0.88 \mathrm{bc}$ & $94.5-97.1$ \\
Indoxacarb & 3 & $30-32$ & $99.0 \pm 0.50 \mathrm{c}$ & $97.9-99.0$ \\
Chlorpyrifos-ethyl & 3 & $30-37$ & $86.3 \pm 1.90 \mathrm{~b}$ & $83.4-89.3$ \\
Chlorantraniliprole & 3 & $32-40$ & $95.1 \pm 1.85 \mathrm{bc}$ & $92.2-97.9$ \\
Novaluron & 3 & $30-40$ & $97.8 \pm 1.02 \mathrm{c}$ & $95.6-97.8$ \\
\hline
\end{tabular}

Number of eggs refers to the number of eggs per egg mass on which topical application of insecticide was made. Sem: standard error of means. 95\% confidence interval of percentage hatched eggs of means. The SEM (standard error of means) and the $95 \% \mathrm{Cl}$ was Bootstrapped 1000 times using the bias corrected acceleration. Means in the same column followed by the same letter are not statistically significantly different by DMRT at $p<0.05$. Each replicate had 10 insects. 


\section{Mortality of hatched larvae $48 \mathrm{~h}$ after hatching}

The mortality rate of larvae $48 \mathrm{~h}$ post hatching was also compared across the different insecticides (Figure 1). The percentage mortality was significantly different $(F=34.3, d f=8,18, P<0.05)$ across the various insecticides. The highest percentage mortality was observed from emamectin-benzoate (84.5\%), and followed by chlorpyrifos-ethyl $(84.4 \%)$. The lowest mortality was recorded from indoxacarb $(23.2 \%)$, followed by novaluron (30.5\%) and lambda-cyhalothrin (38.2\%). The survival of larvae hatched from the insecticide-treated egg masses was impacted by all insecticides. Emamectin-benzoate, chlorpyrifos-ethyl, deltamethrin, spinosad and chlorantraniliprole had higher larvicidal percentages. The dead larvae were probably contaminated by these insecticides as they chew their way out of the egg masses through their mouth or by contact with contaminated surfaces. Indoxacarb is reported to have ovi-larvicidal properties against some Lepidoptera pest such as codling moth and O. nubilalis (Boiteau \& Noronha, 2007), however, this was not the case in the current study as this chemical had lowest number of dead neonate larvae (Figure 1).

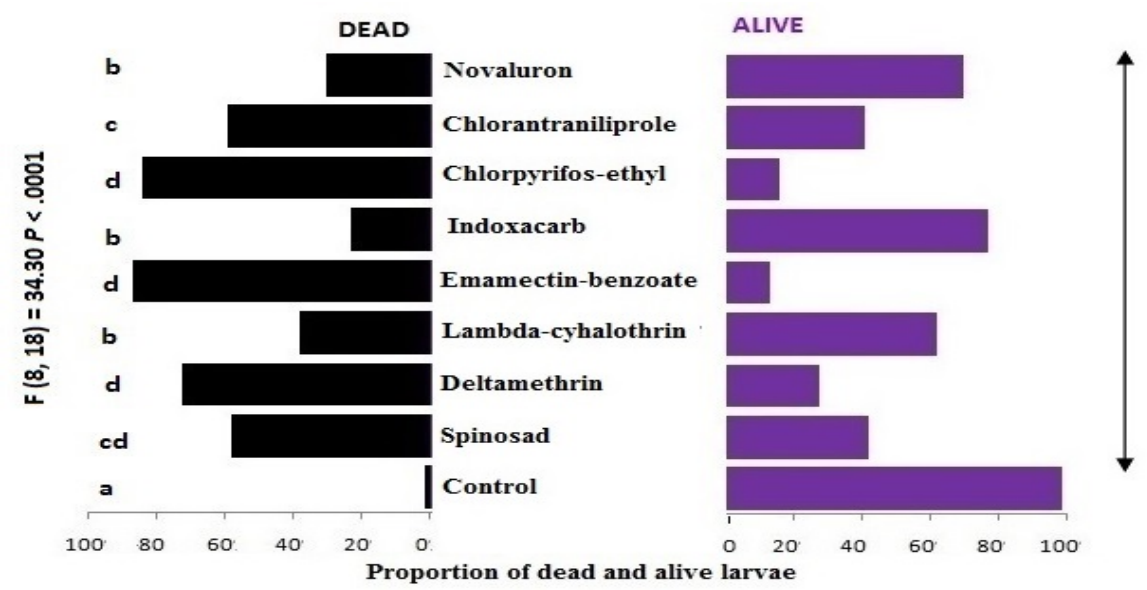

Figure 1. Mean percentage mortality of larvae that hatched from insecticide-treated eggs after $48 \mathrm{~h}$ : comparing percentages of dead and alive across different treatments. Bars with the same letter are not statistically different (DMRT, $\alpha=0.05)$. Arrow shows direction of mean comparison.

\section{Effect of insecticides on first instar larvae}

The effect of the various insecticides on the first instar larvae $72 \mathrm{~h}$ post application is given in Figure 2. The insecticides significantly influenced $(F=8.26, d f=8,18, P<0.05)$ the percentage mortality of first instar larvae. The highest percentage mortality was with emamectin-benzoate $(96.7 \%)$, and lambda-cyhalothrin $(96.3 \%)$. The smallest percentage mortality was with indoxacarb $(62.2 \%)$ and chlorpyrifos-ethyl $(62.6 \%)$. The percentage mortalities recorded in this study were greater than $60 \%$ for all insecticides. The effect of insecticides on the first instar larvae revealed that the first instar larvae were very susceptible to many insecticides. Emamectin-benzoate, pyrethroids and spinosad are known to adversely affect larval stages of lepidopterans such as O. nubilalis, S. nonagrioides, Spodoptera exigua (Hübner, 1808) (Lepidoptera: Noctuidae), P. xylostella (Pineda et al., 2004; Boiteau \& Noronha 2007; Kurt \& Kayis, 2014; Mahmoudvan et al., 2014) including C. partellus (Tanwar et al., 2017; Kumar \& Alam, 2017). Intoxication of the larvae possibly came from contamination from the leaves as they moved around and during feeding. 


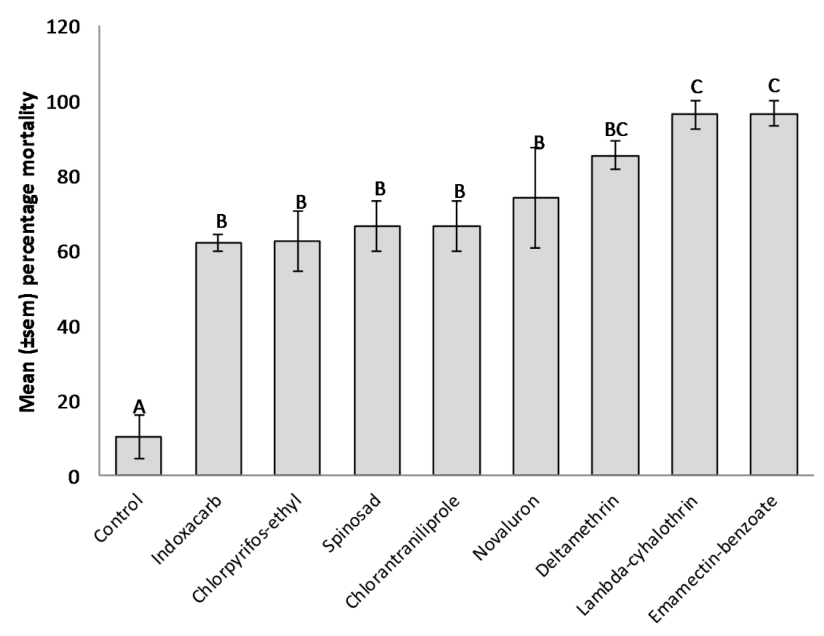

Figure 2. Mean percentage mortality of first instar larvae on insecticide-treated eggs $72 \mathrm{~h}$ post exposure to insecticide-infested leaf disks (percentage mortality was transformed using arcsine transformation before analysis). Bars with the same letter are not statistically different (DMRT, $\alpha=0.05)$.

\section{Feeding behavior}

On completion of the bioassays $(72 \mathrm{~h}$ ), the number of feeding scars made by the larvae on the pesticide-treated leaves were counted and scored. The values were subjected to Kruskal-Wallis ANOVA. The amount of leaves consumed; indicated by the mean rank was significantly different $\left(\chi^{2}=18.8, \mathrm{df}=8\right.$, $\mathrm{P}<0.05)$. The highest mean rank was obtained with the control and novaluron treatments. The smallest mean ranks were recorded with deltamethrin, lambda-cyhalothrin, emamectin-benzoate and chlorantraniliprole (Figure 3). The feeding capability experiment revealed that these insecticides reduced the feeding activity of first instar larvae, thereby ensuring adequate photosynthesis for the plants. In this study, deltamethrin, lambda-cyhalothrin, emamectin-benzoate exerted the greatest negative effect on the feeding capability of the first instar larvae. In a related study, Hannig et al. (2009) investigated the effect of chlorantraniliprole and seven other commercial insecticides on the feeding behavior of four lepidopteran species, P. xylostella, Trichoplusia ni (Hübner, 1803) (Lepidoptera: Noctuidae), S. exigua and Helicoverpa zea Boddie, 1850 (Lepidoptera: Noctuidae). For time to feeding cessation and reduction in feeding, chlorantraniliprole was the fastest-acting insecticide followed of emamectin-benzoate, indoxacarb, lambdacyhalothrin, esfenvalerate and methomyl.

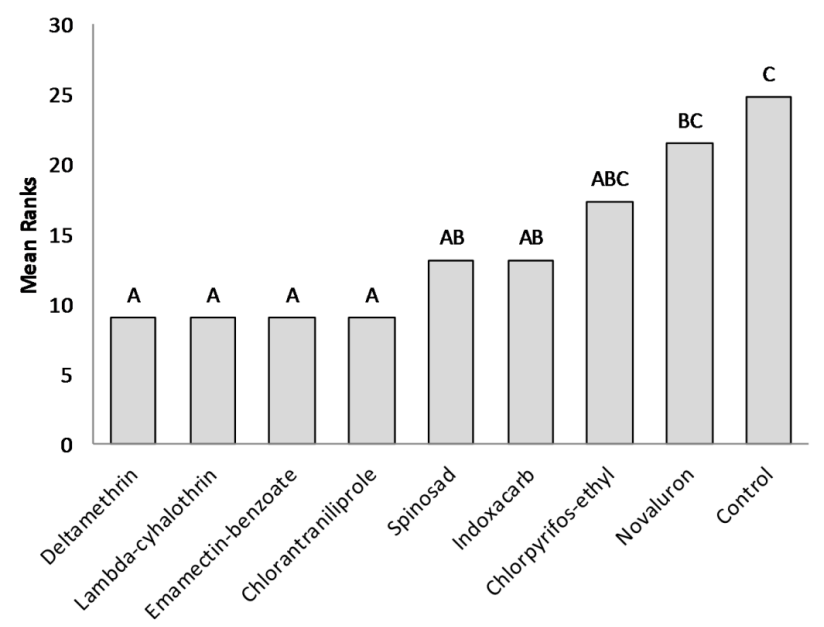

Figure 3. Insect feeding behavior. Mean ranks with the same letter are not significantly different (Duncan's test, $\alpha=0.05$ ). 


\section{Survival analysis}

The mortality of the first instar larvae was assessed every $12 \mathrm{~h}$. Figure 4 shows the Kaplan-Meier curve and Table 3 shows the median time (LT50) and the hazard ratios with their corresponding $95 \% \mathrm{Cl}$ for each insecticide.

The steepness of the slope started from $48 \mathrm{~h}$ for deltamethrin, with 4 larvae surviving to the end of the study. The steepness for lambda-cyhalothrin is similar to that of deltamethrin; however, only two larvae survived to the end of the study. The steepness began from $24 \mathrm{~h}$ for emamectin-benzoate with one larva surviving to the end of the study. The steepness of the slope for indoxacarb started in the $12 \mathrm{~h}$ with 11 larvae surviving to the end. The steepness of the slopes for chlorpyrifos-ethyl and chlorantraniliprole started from $36 \mathrm{~h}$ with 11 and 10 larvae surviving to the end, respectively. Novaluron also had a steep slope beginning from $36 \mathrm{~h}$ with seven larvae surviving to the end (Figure 4). Survival analysis is widely used in scientific research to evaluate the rate of a certain outcome (mortality) over time. The study revealed that emamectin-benzoate had the lowest median time and the highest hazard ratio.

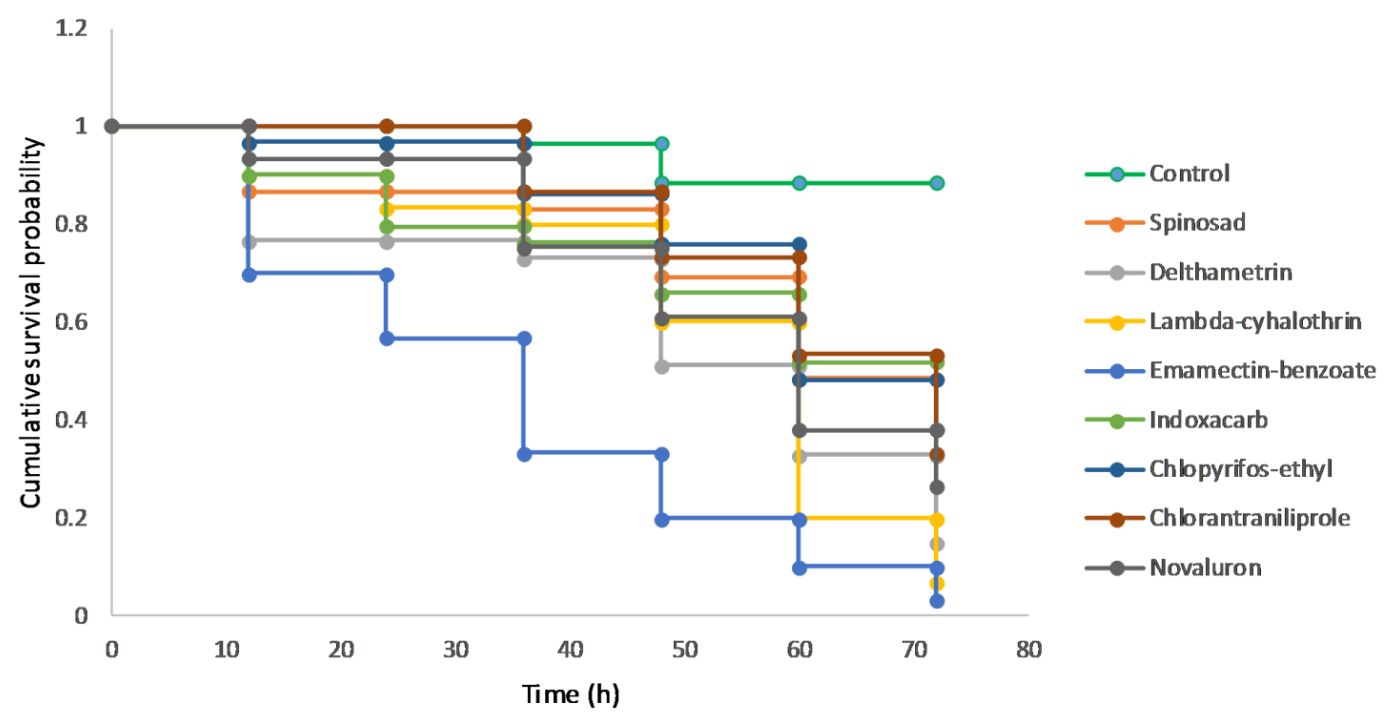

Figure 4. Kaplan-Meier survival curves for first instar larvae of Chilo partellus exposed to different insecticide-treated leaf disks after $72 \mathrm{~h}$.

The reference treatment in this study was the control. Since the mortality in the reference treatment never reached $50 \%$ in any replicate, it is impossible to calculate median time values for the control. The media time ranged from 36 to $72 \mathrm{~h}$. The shortest median time was recorded with emamectin-benzoate (36h, 95\% Cl: 27.3-44.7). The highest median time was recorded with indoxacarb (72 h, 95\% Cl: 56.7-87.3) and chlorantraniliprole $(72 \mathrm{~h}, 95 \% \mathrm{Cl}: 61.9-82.1)$. The median time for all other insecticide was $60 \mathrm{~h}$. For spinosad, the mortality slope was gentle, with 11 larvae surviving to the end of the study. The hazard ratios in this study ranged from 4.91 ( $95 \% \mathrm{Cl}: 1.66-14.6, \mathrm{P}<0.0001)$ with chlorpyrifos-ethyl to 15.6 (95\% Cl: $5.33-$ 45.6), $P<0.0001$ ) with emamectin-benzoate. The mortality of first instar larvae was about 16,10 and 9 times that of the control with emamectin-benzoate, lambda-cyhalothrin and deltamethrin, respectively.

This study was conducted as an initial attempt to evaluate the effectiveness of insecticides used in maize production system in Turkey in order to develop baseline data against $C$. partellus, a newly recorded pest of maize in Turkey. The findings of this study present the short-term efficacy (acute toxicity) of these insecticides. A better understanding of these insecticides requires a long-term (indirect and subtler effect) study on the physiology and behavior of the target pests and their natural enemies (Biondi et al., 2013; Guedes et al., 2016). 
Table 3. Hazard ratios and median time $\left(\mathrm{LT}_{50 \mathrm{~S}}\right)$

\begin{tabular}{lccccc}
\hline Treatment & Hazard Ratio & $95 \% \mathrm{Cl}$ & $\mathrm{LT}_{50}(\mathrm{~h})$ & $95 \% \mathrm{Cl}$ & $P$ values \\
\hline Spinosad & 5.13 & $1.73-15.18$ & 60.0 & $47.15-72.8$ & .003 \\
Deltamethrin & 8.82 & $3.04-25.62$ & 60.0 & $49.56-70.44$ & .0001 \\
Lambda-cyhalothrim & 10.17 & $3.50-29.52$ & 60.0 & $55.05-64.95$ & .0001 \\
Emamectin-benzoate & 15.58 & $5.33-48.56$ & 36.0 & $27.33-44.68$ & .0001 \\
Indoxacarb & 5.38 & $1.82-15.93$ & 72.0 & $56.67-87.33$ & .002 \\
Chlorpyrifos-ethyl & 4.92 & $1.66-14.58$ & 60.0 & $50.09-69.91$ & .004 \\
Chlorantraniliprole & 5.39 & $1.82-15.80$ & 60.0 & $50.38-69.62$ & .002 \\
Novaluron & 6.70 & $2.28-19.72$ & 60.0 & $56.32-63.68$ & .001 \\
\hline
\end{tabular}

Omnibus test for the hazard ratios (chi square $\chi^{2}=65.6, \mathrm{df}=8, \mathrm{P}<0.0001$ ), log rank for $\mathrm{LT}_{50}$ (chi square $\chi^{2}=80.6, \mathrm{df}=8, \mathrm{P}<0.0001$ ) $\mathrm{Cl}$ : confidence interval.

Additional experiments are therefore recommended to determine the ecological effects of these insecticides in field trials. Points of focus could be on the rate and time of application. There are numerous advantages of using insecticides with ovicidal and larvicidal activity, targeting eggs, newly hatched larvae and old larva than insecticides that are only larvicidal. Thus, the role of novaluron and chlorantraniliprole should be considered alongside emamectin-benzoate, lambda-cyhalothrin and deltamethrin as part of an integrated pest management plan.

\section{Acknowledgements}

We are grateful to Assistant Professor Antonio Biondi (Department of Agriculture, Food and Environment of the University of Catania, Italy) for reading and editing the manuscript.

\section{References}

Adan, A., P. Del Estal, F. Budia, M. Gonzalez \& E. Vinuela, 1996. Laboratory evaluation of the novel naturally derived compound spinosad against Ceratitis capitata. Pesticide Science, 48: 261-268.

Ahmed, S., R. R. Khan \& M. Khan, 2003. Some studies of varietal resistance in spring maize against Chilo partellus (Swinhoe) with and without release of Trichogramma chilonis. International Journal of Agriculture and Biology, 5 (4): 552-554.

Ajala, S. O., K. N. Saxena \& P. Chiliswa, 1995. Selection in maize (Zea mays L.) for resistance to the spotted stemborer (Chilo partellus) (Swinhoe). Maydica, 40:137-140.

Ampong-Nyarko, K., R. K. V. Seshu \& K. N. Saxena, 1994. Chilo partellus (Swinhoe) (Lepidoptera: Pyralidae) oviposition on non-host: a mechanism for reduced pest incidence in intercropping. Acta Ecologica, 15: 467-474.

Arabjafari, K. H. \& S. K. Jalali, 2007. Identification and analysis of host plant resistance in leading maize genetypes against spotted stem borer, chilo partellus (Swinhoe) (Lepidoptera: Pyralidae). Pakistan Journal of Biological Sciences, 10 (11): 1885-1895.

Assal, O. M., H. S. A. Radwan \& M. E. Samy, 1983. Egg hatch inhibition in the cotton leaf worm with certain IGRs and synthetic pyrethroids. Journal of Applied Entomology, 95: 259-263.

Beevor, P. S., H. David \& O. T. Jones, 1990. Female sex pheromones of Chilo spp (Lepidoptera: Pyralidae) and their development in the pest control applications. Insect Science and Its Application, 11 (4-5): 787-794.

Bhat, Z. H. \& Z. A. Baba, 2007. Efficacy of different insecticides against maize stem borer, Chilo partellus (Swinhoe) and maize Aphid, Rhopalosiphum maids (Fitch) infesting maize. Pakistan Entomological, 12: 57-61.

Biondi, A., L. Zappala, J. D. Stark \& N. Desneux, 2013. Do biopesticides affect the demographic traits of a parasitoid wasp and its biocontrol services through sublethal effects? PlosOne, 8 (9): e76584. 
Boiteau, G. \& C. Noronha, 2007. Topical, residual and ovicidal contact toxicity of three redused-risk insecticides against the European stem borer, Ostrinia nubilalis (Lepidoptera: Crambidae), on potato. Pest Management Science, 63: $1230-1238$.

Cheruiyot, D., C. A. O. Midega, J. Van den Berg, J. A. Pickett \& Z. R. Khan, 2018. Suitability of brachiariagrass as a trap crop for management of Chilo partellus. Entomologia Experimentalis et Applicata, 166 (2): 139-148.

Chockalingam, S. \& A. Noorjahan, 1984. The ovicidal effect of diflubenzuron on hemiptera bugs, Dysdercus cingulatus and Chrysocoris purpureus. Current Science, 53: 1112-1113.

De Smedt, C., F. Ferrer, K. Leus \& P. Spanoghe, 2015. Removal of pesticides from aqueous solutions by adsorption on zeolites as solid adsorbents. Adsorption Science \& Technology, 33: 457-485.

Galvan, T. L., R. L. Koch \& W. D. Hutchison, 2005. Toxicity of commonly used insecticides in sweet corn and soybean to multicolored Asian lady beetle (Coleoptera: Coccinellidae). Journal of Economic Entomology, 98: $780-789$.

Gardeze, S. R. A., K. Mahmood \& M. Hussain, 1998. Effect of certain pathogenic fungi for the control of maize stem borer (Chilo partellus). Pakistan Journal of Phytopathology, 10: 94-97.

Guedes, R. N. C., G. Smagghe, J. D. Stark \& N. Desneux, 2016. Pesticide-induced stress in Arthropod pests for optimized integrated pest management. Annual Review of Entomology, 61: 43-62.

Guofa, Z., W. A. Overholt \& M. B. Mochiah, 2001. Changes in the distribution of lepidopteran maize stemborers in Kenya from 1950s to 1990s keynote address: Bioecology of Chilo species. International Journal of Tropical Insect Science, 11: 467-477.

Hannig, G. T., M. Ziegler \& P. G. Marçon, 2009. Feeding cessation effects of chlorantraniliprole, a new anthranilic diamide insecticide, in comparison with several insecticides in distinct chemical classes and mode-of-action groups. Pest Management Science, 65 (9): 969-974.

Harris, K. M., 1989. "Bioecology of sorghum stemborer, 63-71". In: International workshop on sorghum stem borers. International Crop Research Institute for the Semi-Arid Tropics (Ed. K. F. Nwanze) (17-20 November 1989, Patancheru, India), $189 \mathrm{pp}$.

Katole, S. R. \& S. K. Mundiwale, 1995. Whorl application of insecticides influenced population of sorghum stem borer at harvest. Journal of Maharashtra Agricultural Universities, 20: 451-452.

Kfir, R., 1993. Diapause termination in the spotted stem borer, Chilo partellus (Lepidoptera: Pyralidae) in the laboratory. Annals of Applied Biology, 123: 1-7.

Kfir, R., 1997. Competitive displacement of Busseola fusca (Lepidoptera: Noctuidae) by Chilo partellus (Lepidoptera: Pyralidae). Annals of the Entomological Society of America, 90 (5): 619-624.

Kfir, R., W. A. Overholt, Z. R. Khan \& A. Polaszek, 2002. Biology and management of economically important Lepidopteran cereal stem borers in Africa. Annual Review of Entomology, 47: 701-731.

Khan, S. M. \& M. Amjad, 2000. Chemical control of maize stem borer (Chilo partellus Swin.). Pakistan Journal of Biological Sciences, 3 (12): 2116-2118.

Kioko, E. N., W. A. Overholt \& J. M. Mueke, 1995. "Larval development in Chilo orichalcociliellus and Chilo partellus: a comparative study in the laboratory, 191-198". In: Proceedings, $10^{\text {th }}$ Meeting and Scientific Conference of the African Association of Insect Scientist (5-10 September 1993, Mombasa, ICIPE Science Press, Nairobi, Kenya), $251 \mathrm{pp}$.

Kumar, H., 2002. Resistance in maize to larger grain borer, Prostephanus truncatus (Horn) (Coleoptera: Bostrichidae). Journal of Stored Product Research, 38: 267-280.

Kumar, R. \& T. Alam, 2017. Effect of some newer insecticides on damage intensity of Chilo partellus Kharif maize. International Journal of Chemical Studies, 5 (6): 675-679.

Kurt, D. \& T. Kayis, 2014. Effect of the pyrethroid insecticide deltamethrin on the hemocytes of Galleria mellonella. Turkish Journal of Zoology, 39: 452-457.

Mahmoudvan, M., A. S. Garjan \& H. Abbasipour, 2014. Ovicidal effect of some insecticides on the diamondback moth, Plutella xylostella (L.) (Lepidoptera: Yponomeutidae). Chilean Journal of Agricultural Research, 71 (2): $226-230$.

Mathur, Y. K. \& K. P. Satyadev, 1992. Evaluation of some important insecticides against Chilo partellus (Swinhoe) and Marasmia trepezalis (Guen.) infesting maize crop. Journal of Entomological Research, 16: 277-282. 
Melaku, W., S. Fritz, E. Kairu \& O. Charlse, 2006. Cereal losses caused by Lepidoptera stem borers at different nitrogen fertilizer rates in Ethiopia. Journal of Applied Entomology, 130: 220-229.

Murenga, M. G., S. M. Githiri, S. N. Mugo \& F. M. Olubayo, 2011. Levels of control of Chilo partellus stem borer in segregating tropical Bt maize populations in Kenya. African Journal of Biotechnology, 10 (23): 4725-4731.

Mutamiswa, R., F. Chidawanyika \& C. Nyamukondiwa, 2017. Dominance of spotted stem borer Chilo partellus Swinhoe (Lepidoptera: Crambidae) over indigenous stemborer species in Africa's changing climate: ecological and thermal biology perspectives. Agricultural and Forest Entomology, 19: 344-356.

Mutyambi, D. M., C. A. O. Midega, T. J. A. Bruce, J. Van den Berg, J. A. Pickett \& Z. R. Khan, 2014. Behaviour and biology of Chilo partellus on maize landraces. Entomologia Experimentalis et Applicata, 153: 170-181.

Ndema, R., F. Schulthless, S. Korie, C. Borgemeister \& K. F. Cardwell, 2001. Distribution, relative importance and effect of lepidopterous borers on maize yields in the forest zones and midaltitude of Cameroon. Journal of Economic Entomology, 94: 1434-1444.

Odindo, M. O., 1990. Potential of Nosema spp (Microspora:Nosematidae) and viruses in the management of Chilo spp (Lepidoptera: Pyralidae). Insect Science and Its Application, 12: 645-651.

Odindo, M. O., 1991. Management of cereal stem borers, especially Chilo partellus using microsporidia. International Journal of Tropical Insect Science, 12 (1-2-3): 51-55.

Ofomata, V. C., W. A. Overholt, S. A. Lux, A. Van Huis \& R. I. Egwuatu, 2000. Comparative studies on the fecundity, egg survival, larval feeding and development of Chilo partellus and Chilo orichalcociliellus (Lepidoptera: Crambidae) on five grasses. Annals of the Entomological Society of America, 93 (3): 492-499.

Okyar, Z. \& S. Kornoşor, 1997. Trakya Bölgesi Noctuidae (Lepidoptera) türlerinin tespiti çalışmaları II. Turkish Journal of Entomology, 21 (3): 197-212.

Overholt, W. A., K. Ogeuah \& P. M. Lammers, 1994. Distribution and sampling of Chilo partellus (Swinhoe) (Lepidoptera: Pyralidae) in maize and sorghum of Kenya Coast. Bulletin of Entomological Research, 84: 367378.

Overholt, W. A., J. Songa, V. Ofomata \& J. Jeske, 2000. "The spread and ecological consequences of the invasion of Chilo partellus (Swinhoe) (Lepidoptera: Crambidae) in Africa, 52-58”. In: Invasive species in Eastern Africa: Proceedings of a workshop held at ICIPE (Ed. S. Miller) (5-6 July 1999, Nairobi, Kenya), ICIPE Science Press, Lyons, $108 \mathrm{pp}$.

Pats, P., B. Eldom \& H. Scovgard, 1997. Influence of intercropping on the abundance, distribution and parasitism of Chilo spp (Lepidoptera: Pyralidae) eggs. Bulletin of Entomological Research, 89: 507-513.

Pineda, S., F. Budia, M. I. Schneider, A. Gobbi, E. Ninuella, J. Valle \& P. D. Estal, 2004. Effects of two biorational insecticides, spinosad and methoxyfenozide, on Spodoptera littoralis (Lepidoptera: Noctuidae) under laboratory conditions. Journal of Economic Entomology, 97 (6): 1906-1911.

Poinar, Jr. G. O. \& A. Polaszek, 1998. "Nematoda, Fungi, Protozoa, Bacteria and Viruses, 283-293". In: African Cereal Stem Borers: Economic Importance, Taxonomy, Natural Enemies and Control (Ed. A. Polaszek). CAB International, Wallingford, UK, $530 \mathrm{pp}$.

Rameash, K., A. Kumar \& H. Kalita, 2012. Biorational management of stem borer Chilo partellus in maize. Indian Journal of Plant Protection, 40 (3): 208-213.

Rauf, A., M. Ayyaz, F. Baig, M. N. Naqqash \& M. J. Arif, 2017. Response of Chilo partellus (Swinhoe) and entomophagous arthropods to some granular and new chemistry formulations in Zea mays L. Journal of Entomology and Zoology Studies, 5 (3): 1351-1356.

Sertkaya, E., V. Akmese \& E. Atay, 2014. First record of spotted stem borer Chilo partellus (Swinhoe) (Lepidoptera: Crambidae) on maize Turkey. Turkish Bulletin of Entomology, 4 (3): 197-200.

Sing, R., O. Koul, P. J. Rup \& J. Jindal, 2009. Toxicity of some essential oil constituents and their binary mixtures against Chilo partellus (Lepidoptera: Pyralidae). International Journal of Tropical Insect Science, 29 (2): $93-101$.

Slabbert, O. \& J. Van den Berg, 2009. The effect of the adjuvant, Break-Thru S240, on whorl penetration and efficacy of foliar insecticide application against Chilo partellus. South African Journal of Plant and Soil, 26: 254-258.

Tanwar, A. K., J. Jindal \& D. S. Brar, 2017. Susceptibility of Chilo partellus (Swinhoe) population to insecticides. Indian Journal of Entomology, 79 (2): 220-222. 
Trisyono, A., B. Puttler \& G. M. Chippendale, 2000. Effect of the ecdyson agonists, methoxyfenozide and tebufenozide on the lady beetle, Coleomegilla maculate. Entomologia Experimentalis et Applicata, 94: 103-105.

Van den Berg, J., 2006. Oviposition preference and larval survival of Chilo partellus (Lepidoptera: Pyralidae) on Napier grass (Pennisetum purpureum) trap crops. International Journal of Pest Management, 52 (1): 39-44.

Van den Berg, J., J. B. J. Van Rensburg \& J. H. Giliomee, 1991. The effect of plant density on the injuriousness of Busseola fusca (Fuller) (Lepidoptera: Noctuidae) in grain sorghum. South African Journal of Plant and Soil, 8: 85-87.

Van den Berg, J. \& M. C. Van den Westhuizen, 1995. Development of chemical control strategy for Chilo partellus (Lepidoptera: Pyralidae) in grain sorghum. South African Journal of Plant and Soil, 12 (3): 105-107.

Van Hamburg, H., 1979. The grain-sorghum stalk-borer, Chilo partellus (Swinhoe) (Lepidoptera: Pyralidae): seasonal changes in adult populations in grain sorghum in the Transvaal. Journal of the Entomological Society of Southern Africa, 42: 1-9.

Yonow, T. D., J. Kriticos, N. Ota, J. Van den Berg \& D. H. William, 2017. The potential global distribution of Chilo partellus, including consideration of irrigation and cropping patterns. Journal of Pest Science, 90 (2): 459-477. 